\title{
Knowledge Gained by Students of Commercial Vegetable Production (ELP) Module
}

\author{
R. A. Patil", K. S. Thorat, N. Sumitha, J. M. Deshmukh and J. M. Shriram \\ Vasantrao Naik Marathwada Krishi Vidyapeeth, Parbhani, India \\ *Corresponding author
}

\begin{abstract}
A B S T R A C T
\end{abstract}
\section{Keywords}

ELP, Commercial

Vegetable

Production

\section{Article Info}

Accepted:

10 January 2021

Available Online:

10 February 2021
The concept of experiential learning follows a cyclic pattern of integrated learning from Experience through Reflection and Conceptualizing to Action and on to further Experience. In the latest revision of UG curricula, the emphasis is given not only on new and emerging areas but also shifting the focus from 'know-how' to 'do-how' so that the undergraduates, after coming out of the universities should become job providers rather than job seekers. The detailed analysis of profile of students indicated that majority of the their parents had agriculture labourer as the occupation, semi-medium land holding and medium annual income, the students had medium social participation, high innovativeness, medium risk orientation, medium scientific orientation, medium management orientation, medium decision making ability, medium self-confidence, medium achievement motivation, medium marketing orientation. Regarding high knowledge of ELP students towards ELP. The result observed that the majority of ELP students had high knowledge about Experiential Learning Programme. Major constraint were faced that Low key importance given preference to students interest while choosing an ELP Programme, followed by Lack of marketing facilities, Lack of informal of review meeting at the end of each week, Lack of field visits and Lack of laboratory facilities .Majority of respondents suggested that giving preference to students interest while choosing an enterprise, arranging proper marketing facilities, conduct of informal review meetings at the end of each week, regular visits to the field to monitor the progress of the ELP Programme, to provide laboratory facilities, respectively.

\section{Introduction}

Agriculture education existed in India even during the medieval period, as evidenced by the historical documentation that the curriculum of Nalanda and Takshashila university had agriculture as one of the eighteen subject taught. The importance of the application of Science and Technology for
Agricultural development was realized as early as in the beginning of century. Among the several commissions appointed for suggesting steps to streamline Agriculture development, the Royal Commission (1926) emphasized the need for a strong research base for agricultural development. In general, appreciation for experiential learning is more of rhetoric in the existing undergraduate 
course curricula. Above all, facilities for learning by experience or hands on training across agricultural universities are either nonexistent or if exist are in a very rudimentary stage of development.

As a result of the IV Deans committee (headed by Dr. S. L. Mehta) report, the ELP was introduced in all the state agricultural universities in India. The VNMKV has also implemented ELP with a load of 20 credits in the VIII semester of B.Sc. (Agri.) with its emphasis on moulding graduates from "job seekers to job providers" in all the constituent colleges from the year 2010-2011. There have been no research studies so far on Experiential Learning Programme Agricultural Universities in India. Therefore, the present study would be one of the pioneering attempts for providing basic information and findings on the above lines. The study is supposed to provide required information to the administrators, planners, policymakers at the helm of the affairs of university to plan better for the improvement in the practical knowledge of the students will enrich the students job satisfaction and there by strengthening the university. This study would enable the programme planners and policy makers to gear up their activities towards improving the Experiential Learning Programme of the students. The different activities in which students are participating more actively and also the activities for which they are not contributing much will be known so as to facilitate policy makers and programme planners to act suitably.

\section{Materials and Methods}

\section{Sampling procedure}

The procedure adopted for selection of the locale of the study and respondents is detailed below.

\section{Locale of the study}

Maharashtra state was purposively selected for the study, as Vasantrao Naik Marathwada Krishi Vidhyapeeth Agricultural University where the proposed study is to be undertaken is located in this state.

\section{Selection of the University/college}

Vasantrao Naik Marathwada Krishi Vidhyapeeth, Parbhani is selected purposively for the present study as it is one and only the Agricultural University existing in Marathwada Region. Two Agricultural colleges viz. College of Agriculture, Osmanabad and College of Agriculture, AlniGadpati were selected for study.

\section{Selection of the Module}

There are three modules conducted under CoA, Osmanabad and CoA, AlniGadpati all of which three modules viz. Commercial Vegetable Production, Commercial mushroom Production, and Commercial Broiler Production out of this Commercial Vegetable Production was selected for study.

After obtaining the total number of students registered for the ELP programme during the eight semester of the academic years 2018-19 and 2019-20 a total of 60 ELP students was selected by the selected college and selected modules proportionate random sampling for the purpose of the present study

\section{Operationalization of variable and their empirical measurement}

The relevant variables for the present study were selected on the basis of thorough review of literature, in consultation with the members of the advisory committee, experts in the field of Agricultural Extension and faculty involved on the implementation of ELP. The 
variables selected for the present study are represented in Table 1.

\section{Devices and methods used for collection of data}

The study required data on several variables from students So, an interview questionnaire was considered most appropriate tool for data collection. The questionnaire was prepared keeping in view the objectives of the study.

\section{Method of data collection}

The data were collected by administering the pretested interview schedule to the students.

\section{Statistical tools used for analysis of data}

To convert the data into meaningful findings the following statistical tools were used; Arithmetic Mean $\overline{(X)}$, Standard Deviation $(\sigma)$, Frequency, Percentage and correlation (r).

\section{Results and Discussion}

\section{Profile of the students of ELP}

\section{Parental occupation}

A glance at the Table 2 revealed that majority (27.50\%) of ELP students parental occupation was agriculture labourer followed by agriculture (16.70\%), agriculture + agricultural labourer $(20.00 \%)$ business $(10.80 \%)$, Service (10.83\%), agriculture and Service (06.67\%), agriculture and Business $(05.83 \%)$ and business and service $(01.67 \%)$ as their parental occupation, respectively. ELP students with their parental occupation as agricultural labour were unable to take advantage of government fees waiver schemes, due to their inability to send their children to corporate schools which become difficult to admit their children in professional course like agriculture after getting qualified in the EAMCET for higher education. This is the reason why they fail to admit their children in professional course like agriculture. Whereas, business people in spite of their financial comfortableness to send their children to corporate schools, they do not have much preference to admit their children in B. Sc. (Ag.) course due to their preoccupied business to provide livelihood.

The present finding of the study was in conformity with the findings of Lakshmi et al., (2013).

\section{Family land holding}

It is revealed from Table 3 that majority $(39.2 \%)$ of the agricultural students were having semi medium size of family land holding, followed by (29.16), (26.66), (05.00), per cent of the students were having marginal, small, medium size of family land holding respectively. From the above findings it can be inferred that, majority of the student's had semi-medium size of family land holding due to that most of the parents would able to pushed their children for pursuing. The probable reason might be that the land holding is reducing day by day due to fragmentation of land in the process of ancestral transfer of land holding due to division of families i.e. Size of land holding is reduces due to pressure of increasing population 20 over the land; thus it proved that division of family and increasing population might be the strong reasons for the semi- medium land holding. These findings are consistent with Niketha et al., (2014)

\section{Family income}

It is elucidated from Table 4 that more than half $(56.67 \%)$ of the agricultural student's had medium family income, followed by $(19.17 \%)$ per cent of the student's were having low family income and $(24.16 \%)$ per 
cent of the student's had high family income. The possible reason might be that as majority of the agricultural student's father were engaged in agricultural farming and also had medium size of family land holding which helps in increasing the income of the student's family followed that most of the student's father were worked in agriculture, Thus most of the students belonged to medium family income group category. These findings are consistent with Shingare (2005).

Table.1 Selected variables and their empirical measurement used for the study

\begin{tabular}{|c|c|c|}
\hline Sl. No. & Variables & Empirical Measurements \\
\hline A & \multicolumn{2}{|l|}{ Independent Variable } \\
\hline 1 & Parental occupation & Schedule was developed. \\
\hline 2 & Land holding & As per Government of Maharashtra \\
\hline 3 & Family income & Schedule was developed. \\
\hline 4 & Social participation & Schedule was developed. \\
\hline 5 & Innovativeness & $\begin{array}{l}\text { Scale developed by Rao (1985) with slight } \\
\text { modification was used. }\end{array}$ \\
\hline 6 & Risk orientation & $\begin{array}{l}\text { Scale developed by Supe (1969) with slight } \\
\text { modification was used. }\end{array}$ \\
\hline 7 & Scientific orientation & $\begin{array}{l}\text { Scale developed by Supe (1969) with slight } \\
\text { modification was used. }\end{array}$ \\
\hline 8 & Management orientation & $\begin{array}{l}\text { Scale developed by Samantha (1977) with } \\
\text { slight modification was used. }\end{array}$ \\
\hline B & \multicolumn{2}{|l|}{ Dependent Variables } \\
\hline 1 & Knowledge & Schedule was developed. \\
\hline
\end{tabular}

Table.2 Distribution of ELP students according to their Parental occupation

\begin{tabular}{|c|c|c|c|}
\hline \multirow{2}{*}{$\begin{array}{l}\text { Sl. } \\
\text { No. }\end{array}$} & \multirow[t]{2}{*}{ Category } & \multicolumn{2}{|c|}{ ELP students (N=60) } \\
\hline & & Frequency & Percentage \\
\hline 1 & Agricultural labourer & 15 & 27.50 \\
\hline 2 & Agriculture & 9 & 16.70 \\
\hline 3 & Agriculture + agricultural labourer & 14 & 20.00 \\
\hline 4 & Business & 08 & 10.80 \\
\hline 5 & Service & 06 & 10.83 \\
\hline 6 & Agriculture + Business & 03 & 05.83 \\
\hline 7 & Agriculture + Service & 04 & 06.67 \\
\hline 8 & Business + Service & 01 & 01.67 \\
\hline 9 & If any other, please specify & 00 & 00.00 \\
\hline & Total & 60 & 100.00 \\
\hline
\end{tabular}


Table.3 Distribution of the agricultural students according to their land holding $n=60$

\begin{tabular}{|c|l|c|c|}
\hline Sl. No. & \multicolumn{1}{|c|}{ Category } & Frequency & Percentage \\
\hline $\mathbf{1}$ & Marginal ( Upto 1ha) & 16 & 26.66 \\
\hline $\mathbf{2}$ & Small (Upto 2ha) & 17 & 29.16 \\
\hline $\mathbf{3}$ & Semi-Medium (2.01 to 4.00) & 24 & 39.20 \\
\hline $\mathbf{4}$ & Medium (4.01 to 10) & 03 & 05.00 \\
\hline $\mathbf{5}$ & Big (10.1 to above) & 00 & 00.00 \\
\hline & Total & $\mathbf{6 0}$ & $\mathbf{1 0 0 . 0 0}$ \\
\hline
\end{tabular}

Table.4 Distribution of the agricultural students according to their family income $n=60$

\begin{tabular}{|c|l|c|c|}
\hline Sl. No. & \multicolumn{1}{|c|}{ Family Income } & Frequency & Percentage \\
\hline $\mathbf{1}$ & Low (Up to 83,079) & 10 & 19.17 \\
\hline $\mathbf{2}$ & Medium $(84,079$ to 3,24,803) & 35 & 56.67 \\
\hline $\mathbf{3}$ & High (above 3,24,803) & 15 & 24.16 \\
\hline & Total & $\mathbf{6 0}$ & $\mathbf{1 0 0 . 0 0}$ \\
\hline
\end{tabular}

Table.5 Distribution of the agricultural students according to their Social participation $n=60$

\begin{tabular}{|c|l|c|c|}
\hline Sl.No. & \multicolumn{1}{|c|}{ Social Participation } & Frequency & Percentage \\
\hline $\mathbf{1}$ & Low (Upto15) & 14 & 23.33 \\
\hline $\mathbf{2}$ & Medium (16 to 20) & 38 & 64.16 \\
\hline $\mathbf{3}$ & High (above 20) & 8 & 12.51 \\
\hline & Total & $\mathbf{6 0}$ & $\mathbf{1 0 0 . 0 0}$ \\
\hline
\end{tabular}

Table.6 Distribution of the agricultural students according to their innovativeness $n=60$

\begin{tabular}{|c|c|c|c|}
\hline Sl. No. & Innovativeness & Frequency & Percentage \\
\hline $\mathbf{1}$ & Low (Upto 15) & 6 & 10.00 \\
\hline $\mathbf{2}$ & Medium (16 to 17) & 29 & 49.16 \\
\hline $\mathbf{3}$ & High (above 17) & 25 & 40.84 \\
\hline & Total & $\mathbf{6 0}$ & $\mathbf{1 0 0 . 0 0}$ \\
\hline
\end{tabular}

Table.7 Distribution of ELP students according to their Risk Orientation $n=60$

\begin{tabular}{|c|l|c|c|}
\hline Sl. No. & Risk Orientation & Frequency & Percentage \\
\hline $\mathbf{1}$ & Low (Upto 14) & 16 & 26.70 \\
\hline $\mathbf{2}$ & Medium (15 to 17) & 26 & 43.30 \\
\hline $\mathbf{3}$ & High ( above 17) & 18 & 30.00 \\
\hline & Total & $\mathbf{6 0}$ & $\mathbf{1 0 0 . 0 0}$ \\
\hline
\end{tabular}


Table.8 Distribution of ELP students according to their Scientific Orientation $\mathrm{n}=60$

\begin{tabular}{|c|l|c|c|}
\hline SI. No. & \multicolumn{1}{|c|}{ Scientific Orientation } & Frequency & Percentage \\
\hline $\mathbf{1}$ & Low (Upto 15) & 18 & 30.80 \\
\hline $\mathbf{2}$ & Medium (16 to 17) & 28 & 45.90 \\
\hline $\mathbf{3}$ & High (above 17) $\quad$ Total & 14 & 23.30 \\
\hline & & $\mathbf{6 0}$ & $\mathbf{1 0 0 . 0 0}$ \\
\hline
\end{tabular}

Table.9 Distribution of ELP students according to their Management Orientation $n=60$

\begin{tabular}{|c|l|c|c|}
\hline Sl. No. & \multicolumn{1}{|c|}{ Management Orientation } & Frequency & Percentage \\
\hline $\mathbf{1}$ & Low (Upto 22) & 9 & 15.80 \\
\hline $\mathbf{2}$ & Medium (23 to 35) & 40 & 66.70 \\
\hline $\mathbf{3}$ & High (above 35) & 11 & 17.50 \\
\hline & \multicolumn{1}{|c|}{ Total } & $\mathbf{6 0}$ & $\mathbf{1 0 0 . 0 0}$ \\
\hline
\end{tabular}

Table.10 Distribution of the ELP students according to their statement wise knowledge gained by Commercial Vegetable Production $n=60$

\begin{tabular}{|c|c|c|c|}
\hline Sl. No. & Commercial Vegetable Production & Frequency & Percentage \\
\hline $\mathbf{1}$ & Do you have knowledge about the seed bed preparation? & 52 & 100.00 \\
\hline $\mathbf{2}$ & $\begin{array}{c}\text { Do you know about ideal spacing in different vegetable } \\
\text { crops? }\end{array}$ & 52 & 100.00 \\
\hline $\mathbf{3}$ & $\begin{array}{c}\text { Do you have knowledge about different methods of sowing } \\
\text { in vegetable crops? }\end{array}$ & 51 & 98.07 \\
\hline $\mathbf{4}$ & $\begin{array}{c}\text { Do you have knowledge about irrigation requirement at } \\
\text { different stages? }\end{array}$ & 41 & 78.84 \\
\hline $\mathbf{5}$ & $\begin{array}{c}\text { Do you know about the various intercultural operation } \\
\text { taken in vegetable crops? }\end{array}$ & 47 & 90.38 \\
\hline $\mathbf{6}$ & $\begin{array}{c}\text { Do you know about the growth regulator in vegetable } \\
\text { crops? }\end{array}$ & 45 & 86.53 \\
\hline $\mathbf{7}$ & $\begin{array}{c}\text { Do you have knowledge about different methods for } \\
\text { controlling of pest and diseases? }\end{array}$ & 44 & 84.61 \\
\hline $\mathbf{8}$ & $\begin{array}{c}\text { Do you know about the signs of maturity in vegetable } \\
\text { crops? }\end{array}$ & 52 & 94.23 \\
\hline $\mathbf{9}$ & $\begin{array}{c}\text { Do you have knowledge about the post harvest management } \\
\text { in vegetable crops? }\end{array}$ & 49 & 75.00 \\
\hline $\mathbf{1 0}$ & Do you know price of vegetable in market? & 39 & \\
\hline
\end{tabular}

Table.11 Distribution of the ELP students according to their knowledge gained by Commercial Vegetable Production students $n=60$

\begin{tabular}{|c|c|c|c|}
\hline Sl. No. & Category & Commercial Vegetable Production $(\mathbf{N}=\mathbf{6 0})$ \\
\hline & & Frequency & Percentage \\
\hline 1 & Low (Upto 7) & 22 & 42.31 \\
\hline 2 & Medium (8 to 9) & 19 & 36.54 \\
\hline 3 & High (above 9) & 11 & 21.15 \\
\hline & & Mean $=8.08$ & S.D.=1.35 \\
\hline
\end{tabular}




\section{Social participation}

It was observed from Table 5 that majority $(64.16 \%)$ of the students had medium participation social participation followed by 23.33 per cent students were having low participation in social participation and 12.51 per cent students had high participation in social participation. From the above findings it can be inferred that good number of the respondents were having medium participation in social participation. These findings are slightly similar with Dhakre (2014)

\section{Innovativeness}

The data presented in the Table 6 revealed that a high majority $(49.16 \%)$ of the ELP students are having medium level of innovativeness followed by the remaining with low level of innovativeness $(10.00 \%)$ and high level of innovativeness (40.84\%), respectively. This might be attributed to the high level of education of ELP students that made them acceptable to the new technologies. The present finding of the study was in congruence with the findings of Prabhugouda (2011).

\section{Risk orientation}

It is evident from the Table 7 that a less than half $(43.30 \%)$ of the ELP students had medium risk orientation followed by 30.00 per cent with high risk orientation and 26.70 per cent of the ELP students with low level of risk orientation, respectively. This might be due to the non-existence of independency of the ELP students in decision making due to the lack of personal source income except their parental income/ governments assistance in the form/ other in spite their experience associated with high education. The present finding of the study was in line with the findings of Mehta and Madhuri (2012).

\section{Scientific orientation}

A glance at the Table 8revealed that a less than half $(45.90 \%)$ of the ELP students had medium scientific orientation followed by 23.30 per cent with high scientific orientation and 30.80 per cent of the ELP students with low level of scientific orientation. Plausible reason for most of the ELP students have to medium and low scientific orientation due to not yet consolidated field experience gained through the course curriculum and RAWEP and what so ever scientific orientation that they have is due to the continuous advisory services provided by the faculty involved in ELP implementation. The present finding of the study was in conformity with the findings of Prabhugouda (2011).

\section{Management orientation}

It could be observed from the Table 9 that majority $(66.70 \%)$ of the ELP students had medium management orientation followed by 15.80 per cent with low management orientation and 17.50 per cent of the ELP students with high management orientation, respectively. The plausible reason for most of the ELP students to have medium to low management orientation is due to the confidence that they gained due to the practical exposure that they have through their course curriculum and RAWEP. Besides, this may also be due to the financial and technical support extended by faculty involved in ELP implementation. The present finding of the study was in obedience with the findings of Prabhugouda (2011).

\section{Knowledge gained by ELP students of Commercial Vegetable Production}

It is evident from the table 14 that, the ELP students according to their knowledge gained by ELP students of Commercial Vegetable Production expressed in the percentage rank 
order of their importance are: knowledge about the seed bed preparation (100.00\%), knowledge about ideal spacing in different vegetable crops (100.00\%), knowledge about the signs of maturity in vegetable crops (100.00\%), knowledge about different methods of sowing in vegetable crops(98.08\%), knowledge about the post harvest management in vegetable crops (94.23\%), knowledge about the various intercultural operation taken in vegetable crops (90.38\%), knowledge about the growth regulator in vegetable crops (86.53\%), knowledge about different methods for controlling of pest and diseases (84.61\%), knowledge about irrigation requirement at different stages $(78.84 \%)$, knowledge price of vegetable in market $(75.00 \%)$,respectively.

\section{Knowledge gained by ELP students of Commercial Vegetable Production}

From above table 15 concluded that, less than half of ELP students (42.31\%) had low knowledge in Commercial Vegetable Production module of ELP Programme followed by 36.54 per cent of ELP students had medium knowledge in Commercial Vegetable Production production of ELP Programme. However, 21.15 per cent of ELP students had high knowledge in Commercial Vegetable Production module of ELP Programme, respectively. The possible reasons may be majority of ELP students of Commercial Vegetable Production were belonged to high innovativeness, medium risk orientation and decision making ability. The other possible reason might be that decision making of ELP students is good due to self-confidence of ELP students.

\section{References}

Dhakre, D. S., 2014. Aspiration of agriculture students towards agriculture enterprise in West Bengal: A case study. EES, Institute of Agriculture, PSB, Visva Bharati Santiniketan. WB. Indian Res. J. Extn. Edu. 14 (1).

Lakshmi, T., Kalyan, N.V. and Prasad, S.V., 2013.Career preferences of undergraduate agricultural students of S.V. agricultural college, Thirupati. The Andhra Agricultural Journal. 60 (1): 213-219.

Mehta, B.M., and Madhuri, S., 2012. Entrepreneurial behaviour of mango growers of Valid district of Gujarat state. Indian Research Journal of Extension Education. 12(1): 78-82.

Niketha, L., Pallavi, D., Amit Singh Suryawanshi. And Sajad Ahmed Wani., (2014). Aspirational analysis of girl students involved in agricultural Profession. Agricultural Science Digest, 34 (4): 263-267.

Prabhugouda, K., 2011. Entrepreneurial behaviour of pomegranate growers in Koppal district of Karnataka. M. Sc. (Ag.) Thesis. Acharya N.G. Ranga Agricultural University, Hyderabad. India.

Shingare, R., 2005. Study of attitude and occupational aspiration of under graduate Veterinary science and Animal Husbandry College students of Gujarat M. Sc. (Agri.). Thesis (Unpub.), A.A.U., Anand.

\section{How to cite this article:}

Patil, R. A., K. S. Thorat, N. Sumitha, J. M. Deshmukh and Shriram, J. M. 2021. Knowledge Gained by Students of Commercial Vegetable Production (ELP) Module. Int.J.Curr.Microbiol.App.Sci. 10(02): 995-1002. doi: https://doi.org/10.20546/ijcmas.2021.1002.117 